\title{
РЕЦЕНЗІЯ НА МОНОГРАФІЮ О. А. ГРИТЕНКО «ПРОГРЕСИВНА СИСТЕМА ВИКОНАННЯ ТА ВІДБУВАННЯ ПОКАРАННЯ У ВИДІ ПОЗБАВЛЕННЯ ВОЛІ: ТЕОРЕТИЧНІ ТА ПРАВОВІ АСПЕКТИ ${ }^{1}$
}

Копотун I. M.

Обґрунтування актуальності та своєчасності дослідження обраної теми зумовлюється багатьма чинниками, серед яких на особливу увагу заслуговують: проблеми стану дослідження питання реалізації прогресивної системи виконання та відбування покарання у виді позбавлення волі; стан відповідності (невідповідності) вітчизняного кримінально-виконавчого законодавства міжнародно-правовим стандартам та міжнародному досвіду; суто теоретичні аспекти, пов'язані 3 понятійним апаратом, ознаками відповідних понять та категорій, виокремленням форм реалізації прогресивної системи; чинні проблеми законодавчого визначення порядку та підстав зміни умов утримання засуджених під час відбування ними покарання у виді позбавлення волі тощо. Кожний із цих чинників $є$ самодостатнім із точки зору доведеності доцільності більш глибинного та комплексного дослідження теоретичних та правових аспектів реалізації прогресивної системи виконання покарання у вигляді позбавлення волі в Україні.

Монографічне дослідження, підготовлене кандидатом юридичних наук, доцентом О.А. Гритенко, $\epsilon$ актуальним та своєчасним, оскільки вперше у вітчизняній кримінально-правовій науці здійснено комплексне дослідження, присвячене як проблемам теорії, так і законодавства в частині реалізації положень міждисциплінарного інституту - прогресивної системи виконання та відбування покарання у вигляді позбавлення волі. Дане дослідження спрямоване на теоретичне обґрунтування та вироблення пропозицій із удосконалення чинного кримінально-виконавчого законодавства у частині особливостей застосування різних форм зміни умов утримання під час відбування покарання, усунення суперечностей у змісті правового статусу засуджених, до яких застосовуються різні форми прогресивної системи, вдосконалення матеріальних підстав прогресивної системи вико- нання під час виконання та відбування покарання у вигляді позбавлення волі.

Про комплексний характер дослідження свідчить методологія дослідження. У роботі використовувалися різноманітні методи наукового пізнання (історичний, систематичний, правовий, догматичний, соціологічний, тощо), що дозволили, зокрема:

1) комплексно в ретроспективі вивчити положення кримінально-виконавчого права, що сприяє не лише усвідомленню чинного стану використання елементів прогресивної системи виконання та відбування покарання у вигляді позбавлення волі, але й виокремленню тенденцій його реформування;

2) на підставі узагальнення вітчизняного досвіду нормотворення та правозастосування висунути й обґрунтувати ряд важливих пропозицій, здатних вплинути на ефективність національного законодавства у сфері реалізації прогресивної системи виконання та відбування покарання у вигляді позбавлення волі.

Теоретичні положення, висновки та рекомендації, які містить монографія, достатньою мірою обґрунтовані. Детальний, поглиблений i аргументований розгляд більшості питань монографії дозволив кандидату юридичних наук, доценту О.А. Гритенко висловити пропозиції щодо вдосконалення чинного законодавства та практики його застосування. Вони є аргументованими та заслуговують на увагу.

У першому розділі монографії авторка справедливо основну увагу приділяє історичним та сучасним тенденціям щодо визначення основних напрямків реформування кримінально-виконавчої системи України.

У другому розділі монографії звертається увага на проблеми змісту, сутності, мети, спрямування поняття та ознак прогресивної системи виконання та відбування покарання. У своїх висновках із цих 
питань автор відштовхується від доволі значного обсягу доктринального матеріалу, що підтверджує відсутність єдності практично в кожній із проблем.

У третьому розділі монографії визначається проблеми щодо вдосконалення кримінально-виконавчого законодавства України в частині відтворення елементів та форм прогресивної системи виконання та відбування покарання у вигляді позбавлення волі. Слушною $\epsilon$ думка авторки стосовно того, що аналіз деяких положень чинного кримінально-виконавчого законодавства, в частині відтворення сутності прогресивної системи виконання та відбування покарання у вигляді позбавлення волі, надає підстави визначитися з доцільністю подальшого їх дослідження.

Практична значущість полягає в розробленні пропозицій, спрямованих на вдосконалення кримінально-виконавчого законодавства України, можливості їх використання для підготовки підручників та навчальних посібників із дисциплін «Кримінально-виконавче право України», «Кримі- нальне право», в навчальному процесі юридичних закладів.

Приймаючи до уваги всі вищезазначені аспекти, можна стверджувати, що представлена на рецензування монографія «Прогресивна система виконання та відбування покарання у виді позбавлення волі: теоретичні та правові аспекти», підготовлена кандидатом юридичних наук, доцентом О.А. Гритенко, є певним внеском у науку кримінального та кримінально-виконавчого права, а зроблені висновки та пропозиції мають практичний інтерес. Робота є завершеною, оригінальною науковою працею, підготовлена на достатньому теоретичному рівні, відповідає вимогам, що висуваються до даного виду робіт, і може бути рекомендована до друку.

Копотун I. M., доктор юридичних наук, професор, професор кафедри кримінального права та судочинства

Міжнародного економіко-гуманітарного університету імені академіка Степана Дем'янчука 